\title{
Constructing Institutional Interests: EU and NATO Enlargement ${ }^{1}$
}

\author{
K.M. Fierke \\ Queen's University of Belfast, Northern Ireland \\ k.fierke@qub.ac.uk \\ Antje Wiener \\ Institute for Political Science, University of Hannover \\ a.wiener@mbox.ipw.uni-hannover.de
}

Queen's and Hannover, 9 May 1999

Paper prepared for presentation at the ECSA Sixth Biennial International Conference, Pittsburgh, USA, 2-5 June 1999

Forthcoming in:

Journal of European Public Policy (1999), Vol. 6, No. 5

\footnotetext{
${ }^{1}$ We thank William Wallace and Jan Zielonka for encouraging us to move ahead with the project and the Politics Group at Nuffield College, Oxford for providing Antje Wiener with a visitorship in 1998, while Karin Fierke was a Prize Research Fellow there. Earlier versions of the article have been presented at a workshop on "The Social Construction of European Integration" at Fenmøller, Denmark, June 1998, and the British International Studies Association meetings, University of Sussex, December 1998. We thank participants of both, and specifically, two anonymous reviewers, Knud Erik Jørgensen, Veronique Pin-Fat, Jeff Checkel, Frank Schimmelfennig, Thomas Diez and Ulrich Sedelmeier for comments on earlier versions. The responsibility for this version is ours.
} 
The eastward enlargement of the European Union (EU) and the North Atlantic Treaty Organisation (NATO) is likely to transform the political and economic landscape of Europe. Yet there has been little analysis of the relationship between the two parallel processes. Instead, two separate literatures approach eastward enlargement from different angles. Work on EU enlargement focuses more on institutional, formal agreements and procedures than on * the politics of enlargement and how it came about. ${ }^{2}$ The question is important because neither EU nor NATO enlargement was clearly envisioned in the immediate aftermath of the Cold War. The EU had taken steps, with the Single European Act (SEA), the common market project of 'Europe 92 ' and the Maastricht Treaty, to deepen European integration; many saw the potential of widening to a group of 'fragile democracies' in the East as undesirable if not destabilising.

The more lively political and academic debate over NATO expansion has tended to revolve around the question of whether this move eastward will recreate the division of Europe or bring greater peace and stability to a fragmented region. ${ }^{3}$ In the immediate aftermath of the Cold War, western publics were questioning why NATO, as a defensive alliance set up to contain the Soviet Union, was even necessary or relevant in the absence of its Cold War enemy. Many, at the time, assumed that the more comprehensive Conference on Security and Co-operation in Europe (CSCE) would provide the framework for future security co-operation in a larger Europe, including Russia (Havel 1991: 35).

\footnotetext{
${ }^{2}$ Avery and Cameron 1998, Grabbe and Huges 1998, Mayhew 1998, Preston 1997; Schimmelfennig 1998, Sedelmeier 1998 for theoretical work

${ }^{3}$ Brown 1995; MccGwire 1998; Mandelbaum 1996; and, Asmus, Kugler and Larrabee 1995; Glaser 1993; Sloan 1995, respectively.
} 
As a result, one can question how and why the expansion of both institutions is proceeding despite questions about the material interest in doing so and in the face of an increasingly negative public opinion. ${ }^{4}$ In other words, why has enlargement become 'inevitable'? The empirical question relates to a larger theoretical issue about how organisations know their interests and how these interests are transformed.

Constructivists have argued that enlargement of the EU can more readily be explained by normative considerations than in terms of objective interests (Schimmelfennig 1998). In this respect, a difference between the two organisations is apparent. Enlargement has been at the heart of the European Community's (EC) identity from the start. There have been a range of accessions since the EC began with the original six in 1957. The EU's acquis communautaire provides an important normative basis for enlargement ${ }^{5}$ However, the current potential is qualitatively different in scope than past accessions, which have only involved a few countries at a time. Eastern expansion could incorporate up to fifteen new countries, and is likely to dramatically transform the institutions of the community. ${ }^{6}$

NATO, by contrast, lacks any formal equivalent of the aquis and, as a Cold War alliance, the expansion of NATO had been largely unthinkable. In that context, a request by, for instance, Poland to join NATO could have provided the impetus for nuclear war. Since the end of the Cold War, and the disappearance of the Soviet Union, this concern has faded. The key issue for the alliance is less one of adding new members than whether it is possible to do so without drawing clear boundaries between those 'inside' and 'outside' the alliance. The

\footnotetext{
${ }^{4}$ See for example public opinion changes which show an increased scepticism towards NATO enlargement. While in 1996 majorities of $56 \%$ in France, $61 \%$ in Germany, and $66 \%$ in Britain welcomed enlargement, percentages changed significantly to $39 \%$ in France, $38 \%$ in Germany and $42 \%$ in favour of NATO enlargement in 1997. (European Opinion Alert, USIA Office of Research and Media Reaction, 7.2.97, c.f. Statewatch, DB2WEB 2.10, 1998).

${ }^{5}$ The acquis communautaire has come to be the guiding framework for enlargement procedures in particular (Michalski and Wallace 1992). The accession acquis entails "the whole body of rules, political principles and judicial decisions which new Member States must adhere to, in their entirety and from the beginning, when they become members of the Communities" (Gialdino 1995, 1090).

${ }^{6}$ The Central and Eastern Europe candidates include Bulgaria, the Czech Republic, Estonia, Hungary, Latvia, Lithuania, Poland, Romania, Slovakia and Slovenia.
} 
current challenge is to expand without reviving Cold War tensions or recreating a division of Europe

The difference between the two organisations only highlights the question of how the parallel processes of expansion became possible. Our argument relates both processes of expansion to the social construction of European identity during the Cold War. In that context, the specific Western identity of both organisations was constituted by shared democratic norms and practices and in opposition to the communist political order to the East. The East was therefore an important reference point for the social construction of western Europe. The post-Cold War context poses a dramatic challenge to this identity, a challenge that is clearly:demonstrated by the respective enlargement processes. Now, the eastern Europeans, previously the West's Other, seek membership in western organisations. In this respect, the empirical question relates to a larger theoretical issue about how institutional identities and interests are transformed.

The article is divided into three sections. Section $I$ explores the theoretical question at the core of the rationalist-constructivist debate as it relates to NATO and EU expansion. Section 2 builds a theoretical argument about the relationship between speech acts, norm construction and institutional interests. Section 3 develops a research agenda for comparing the expansion of the EU and NATO within this framework.

\section{The Theoretical Question}

A rationalist approach to interests or preferences might proceed as follows. If we assume that the preferences or interests of actor $A$ are $X$, that is, if we takes these preferences as given, we can expect a particular outcome. For instance, if the EU, in the late 1980s, had an interest in deepening, as opposed to widening, we could expect an outcome that would contribute to the realisation of this interest. Rationalists make an argument that given a set of preferences or interests we can anticipate certain rational outcomes. The problem, in this case, is not to 
explain outcomes given a set of stable preferences, however; rather it is to gain some insight into the changing identity and interests of NATO and the EU. We therefore approach the problem from a slightly different angle than the rationalists. Rationalists take the context as given; we want to problematise the context. Rather than taking the rules of any particular game for granted, and focusing on the rationality of decisions within an assumed context, we want to elaborate on the context itself and how the changing identities and interests of both organisations were invested with social and political meaning.

Constructivists have challenged the rationalist assumption of exogenously given interests, arguing that interests are constructed in historically specific circumstances and that a context of social and cultural norms shapes actor identity and behaviour. ${ }^{7}$ Consistent with this assumption, we explore interest formation and change in the process of eastern enlargement. We ask how and why eastern expansion became part of the policy agenda despite serious doubts, in the early aftermath of the Cold War, that expansion was in the interest of either organisation.

Sociological constructivists such as Emmanuel Adler (1997) and Alexander Wendt (1992) have explored the nature of changing games, and of the reconstitution of identities and interests; however, in these accounts, meanings are instrumentally deployed by rational actors or rationality appears to be prior to the development of any shared context of meaning. ${ }^{8}$ Thus; Wendt's analysis of the first encounter between alter and ego emphasizes the cost-benefit calculations of the two players. Alter and ego begin without a common language or history but possess a desire to survive and certain material capabilities. Through a process of signalling and interpreting, alter infers the costs and probabilities that ego's intent is malign or friendly. Wendt focuses on an originary situation, prior to the development of any kind of relationship and is therefore not easily adapted to a situation where alter and ego have a past

\footnotetext{
${ }^{7}$ For an elaboration on various strands of constructivist approaches in IR, see Christiansen, Joergensen and Wiener (1999).

${ }^{8}$ Doty (1998) and Campbell (1998) have this critique in greater detail:
} 
and are, therefore, already embedded in a context of social interactions. However, as Doty (1997: 387) notes, encounters "always take place in a context wherein traces of prior meanings and representations are already in place and become interwoven in new experiences. “

If we agree that a priori meanings constrain reasoning about the other, and not an $a$ priori rationality, then a sociological constructivist approach can provide only a limited understanding of the current enlargement process. For instance, EU enlargement can in part be explained by the commitment, embodied in the aquis communautaire, to widen to other democratic states in Europe. Enlargement fits within the shared norms of the Union, and these $\ldots$ norms have a stronger pull than 'objective' interests. There are two problems with this argument, however. First, the institutionalist argument begs the question of why the rules and norms of the acquis communautaire would override other interests? Second, if NATO, as an institution that lacks the formal equivalent of the acquis, is also expanding the explanation must in part lie elsewhere. Given the parallel processes of expansion we raise a question about the role of another level of norms shared by the two organisations, which may be propelling the expansion process.

To provide an explanation for both processes of enlargement, we draw on on Wittgensteinian constructivism where meaning and language are central to the constitution of identity and interest (Fierke 1998; Kratochwil 1989; Onuf 1989; Zehfuss 1998). Scholars in this tradition argue that once one enters the realm social action and language, norms cannot be reduced to causes as sociological constructivists often do (for a critique see also Checkel 1999). Thus Kratochwil (1989: 5-6) points out that our conventional understanding of social action and of the norms governing them is defective because of a fundamental misunderstanding of the function of language in social interaction, and because of a positivist epistemology that treats norms as 'causes'. Communication is therefore reduced to issues of describing 'facts' properly, 
i.e. to the 'match' of concepts and objects, and to the ascertainment of nomological regularities. Important aspects of social action such as advising, demanding, apologizing, promising etc., cannot be adequately understood thereby. Although the philosophy of ordinary language has abandoned the 'mirror' image of language since the later Wittgenstein, the research programs developed.within the confines of logical positivism are, nevertheless; still indebted to the old conception. [emphasis in text]

Building on this opening towards language, we examine the process of norm construction in the dialectical relationship between context, speech acts, and institutional transformation. While rationalists ask what outcome, given a set of preferences, can be expected, we instead ask in what kind of context NATO and EU expansion would be meaningful and rational. Rather than looking for a unidirectional relationship between preferences and outcomes, we examine how, in a changing context, identities and interests are mutually constituted through a process of interaction. The purpose of this analysis is to reflect on how, given the dramatic change of context with the end of the Cold War, the meaning of the Cold War 'promise' of Helsinki was transformed into a threat. We have chosen to focus on Helsinki because it is a promise that transcended both organisations, yet, given its three baskets, was related to the mandates of each.

\section{Speech Acts, Contextual Change and Institutional Interests}

This section outlines the contours of a more extensive empirical research programme. Three concepts - speech acts, contextual change, and institutional interest-are developed against the background of the Cold War and post-Cold War transformations. The empirical examples illustrate that the rationality of both decisions has to be situated in a context of a priori and changing meanings in regard to the identity and norms of the West. 
While the EU and NATO are usually studied as separate phenomena, there is a historical relationship between the development of their respective roles and practices. The creation of western institutions such as the EC and NATO in the late 1940s and early 1950s was inspired by a notion of security that was both economic and military. The European Coal and Steel Community was set up in the hope of binding the economic fate of Germany and France such that they would have a common interest in avoiding war. NATO was established for the purpose of protecting western Europe from the Soviet Union. The security provided by the one organisation faced inward; the security provided by the other, faced outward. Both notions of security reinforced the importance of a border of order, which ran through the centre of Europe.

The 'iron curtain' represented that border of order for EU and NATO, in so far as it played a crucial role in the process of identity formation for both organisations. States became members of each and, akin to political citizenship rights, acquired-qua membership-the right to vote within the order of each respective organisation. However, if it is assumed that the discourse of citizenship not only creates a border of order by defining who is inside and who is outside but also suggests that a community is more than the sum of its parts (Kratochwil 1994), then, this discourse is also constructive towards a notion of belonging beyond the right to membership. ${ }^{9}$

Similarly, over time, NATO and EU membership has come to entail a notion of belonging to a community, or, for that matter, a particular order which was built on liberal democratic principles that were to a large extent established and sustained by negative definition with the other side of the iron curtain, the communist east. The specific institutional identities were profoundly challenged by the post-Cold War situation. Enlargement is not simply a means to extend membership to another state; it also involves incorporating what

\footnotetext{
${ }^{9}$ Such practice is exemplified in the republican notion of identity formation through political debates among citizens, or, the conflictive process of establishing the institutional terms of citizenship, i.e. "citizenship practice" (Preuss 1995, Habermas 1991 and Wiener 1998a, 1998b, 305, respectively).
} 
was previously the Other, i.e. from another type of order. Enlargement in the post-Cold War context hence not only presents the challenge of a missing Other; both organisations also face the prospect of incorporating of members whose notion of belonging developed in a different context. Transgressing the Cold War borders of order, therefore, raises the question of belonging anew.

In the context of the Cold War, aside from early talk about the 'rollback' of Communism, eastern Europe became the largely forgotten half of Europe, invisible against the background of the Soviet Union's dominating presence. The containment policy of NATO, which necessarily involved the U.S., was defined primarily in relation to the Soviet Union. Until the period of détente, EC policy was largely inward looking, preoccupied with the re-emergence of western European economies. The self-definitions and normative ideals of both NATO and the EU were defined in opposition to the East. Their openness, democracy and freedom were contrasted with a closed totalitarian neighbour. The articulation of the West's normative ideals served primarily to reinforce its own identity vis à vis the Other.

Prior to détente, there was some hope that the two Germanies would be reunified and this was reflected in the failure to recognise the new GDR. This hope of obliterating the division of Europe subsided with détente. Eastern and western European states created a framework of peaceful coexistence. The common principles that would guide their relationship were embodied in the three baskets of the Helsinki Final Act, which was signed by states in both East and West in 1975. Expansion was a non-issue; détente cemented the division of Europe, granting Communist regimes in the East a legitimacy they had not previously enjoyed. Nonetheless, the Helsinki process was highly politicised from the start, as states in each bloc selectively interpreted the document (Bloed, 1990: 283). Western states emphasised western values, and in particular the primacy of human rights, while eastern states emphasised disarmament provisions, non-interference in their affairs and the hope of economic aid. For the West, Helsinki represented the embodiment of western ideals of the 
free flow of information people, and goods across the division of Europe as well as the possibility of greater respect for human rights. The 'promise' articulated in the human rights basket of the Final Act first came back to haunt the eastern European communist regimes, during the last part of the Cold War, and later, after its end, western institutions. In what follows, we articulate the theoretical relationship between speech acts, contextual change and the challenge to institutional identity by reflecting on the 'promise' of Helsinki.

\section{Speech Acts: The Promise of Helsinki}

According to NATO Review "The ultimate significance of the Final Act of the Conference' onSecurity and Cooperation in Europe, signed in Helsinki on 1 August 1975, depends on the degree to which all its provisions are implemented by all the participants. Although the Final Act does not, in Western eyes, have the force of law and its implementation is voluntary, there is nevertheless a strong moral obligation on signatories to translate its promises into reality." 10 . That is, the significance of the Final Act lay less in the force of law than in constructing a moral obligation. The goal was to translate the promise of Helsinki into reality. This promise is an example of a speech act. There is a long tradition of speech act theory, which has recently begun to seep into the international relations literature. ${ }^{11}$

Several ideas at the core of this theory are relevant to our analysis. First, certain categories of speech are not simply descriptive or conveying information, but are acts in and of themselves. Acts of this kind are referred to as 'performatives.' Saying something is doing something (Kratochwil 1989, 8). For instance, when someone says 'I do' in the context of marriage, they undertake an act which has a range of moral and legal consequences; the act constitutes the marriage, or brings it into being. Secondly, speech acts are dependent on a context for their meaning. The meaning of a promise in the context of a marriage is quite

\footnotetext{
${ }^{10}$ (emphasis added), NATO Review, 1975, 'Implementation of the Final act of the CSCE'; see also, Luns 1976
} 
different than a promise to pick up clothes at the cleaner or the promise of Helsinki. It is by virtue of the context, that acts, such as promises or threats have illocutionary force and prelocutionary effects. The two can be distinguished by the force of variously promising, ordering, threatening, and the meaning attached to these actions, as opposed to the effect of promising, forcing or frightening on the addressee, or the bringing about of effects on an audience (Levinson 1983, 236). Both the illocutionary force and prelocutionary effects are dependent on context.

The third point, which is somewhat less obvious, is that speech acts do not necessarily presuppose any face-to-face communication between communicants. All that matters is that the content of the speech act is conveyed from one party to another. If state $\mathrm{X}$ targets its missiles on state $\mathrm{Y}$, for instance, a threat may be communicated, even if the threat was not spoken. ${ }^{12}$ The propositional content of a promise or threat may also be conveyed through public discourse toward an other, rather than in a direct face-to-face exchange. In this light, it is perfectly reasonable to understand the commitment of states, in the context of the Helsinki Final Act, as the expression of a speech act of 'promising' to undertake a range of activities. This promise was communicated both to other states involved in the process and to their respective publics.

The human rights example is particularly interesting for examining the relationship between speech act and context. The illocutionary force and perlocutationary effect of the eastern promise to respect human rights manifested itself on two levels, that is, toward eastern European citizens' initiatives, who pointed out the discrepancy between the promise and corresponding acts by eastern governments, and towards western countries, who, given the priority attached to human rights, encouraged the dissident eastern Europeans. By 1976 and 1977 the Workers' Defence Committee (KOR) in Poland and the Charter 77 in

\footnotetext{
${ }^{11}$ Austin 1962, Searle 1969, Levinson 1983 and Duffy, Frederking and Tucker 1998, Kratochwil 1989, Buzan, Waever, and De Wilde 1998.

${ }^{12}$ We thank Gavan Duffy both for this particular example and for clarifying this point.
} 
Czechoslovakia, were pointing out the discrepancy between the promise of eastern governments to respect human rights and the abusive treatment they were receiving for exposing violations. In this respect, eastern citizen's initiatives magnified the moral obligation which the promise entailed.

Western countries reinforced this breach of promise by referring back to Helsinki. For instance, in response to the Declaration of Martial Law in Poland in December 1981, the Special Ministerial Session of the North Atlantic Council stated that "The process of renewal and reform which began in Poland in August 1980 was watched with sympathy and hope by all who believe in freedom and self-determination; it resulted from a genuine effort by the overwhelming majority of the Polish people to achieve a more open society in accordance with the principles of the Final Act of Helsinki." ${ }^{13}$ The West not only recognised the role of the Helsinki Principles in encouraging this dissidence, but also the commitment to recognise the right of individuals to help in ensuring full implementation, ${ }^{14}$ and the responsibility of the West toward those attempting to uphold 'western' ideals. As Lord Carrington (1983) stated: ..

We must face squarely the complex moral and political dilemmas which developments in Eastern Europe pose for the West. Whatever we do, the Soviet Union will accuse us of subverting these countries. They are bound to say this because they cannot contemplate the enormity of their own failure in the area. Free societies have a power of attraction of which it would be perverse to be ashamed, and we should not be afraid to subvert by example. Our prime concern must be for the peoples of these countries themselves. We have a historical duty, and a political and moral responsibility to uphold their right to freedom and self-determination (emphasis added).

\footnotetext{
${ }^{13}$ Special Ministerial Session of the North Atlantic Council, 11 January 1982, 'Declaration of Events in Poland,' NATO Review, no (1982) p. 28

${ }^{14}$ Solesby 1978, Luns 1979, Nimetz, 1980, de Carmoy 1982
} 
Carrington thus emphasised that the West should not encourage revolution in the East, but rather reform. Consistent with detente, the goal was not to overturn the eastern order (and therefore the western border of order) but to open it up so that the people there might live under freer conditions. The recognition of a moral obligation toward the eastern dissidents who were exposing the eastern failure to abide by its promise of human rights, manifests a further illocutionary force in this context. The praise of eastern human rights dissidents was situated again and again within a larger argument about the need for western activists who were questioning their own government's policies in the area of disarmament, to recognise what precisely' NATO, in particular, was defending, i.e. western ideals of democracy and human rights (Levi 1982, de Carmoy 1982, Carrington, 1983, Defois 1984). In both of these respects, the promise of Helsinki, articulated in the context of the Cold War, served primarily to reinforce the border of order separating East and West.

\section{Changing Contexts, Changing Meaning}

From 1989 to 1991, the European political landscape was transformed with the dismantling of the Berlin Wall and the collapse of the Warsaw Pact and the Soviet Union. Both the EU and NATO were forced to redefine their identities as a result. For the EU, the dramatic changes accompanying the end of the Cold War created pressures to expand the community at a time when it had been preparing to further 'deepen' the integration of existing members. For NATO, as a military alliance, designed for the defence of the West within the Cold War, the key issue in the immediate aftermath was less whether NATO would expand than whether the Alliance was necessary in the absence of its former antagonist (Lubkemeier 1991; Ando 1993). Against the background of a series of unanticipated changes that raised questions about the future identity of both organisations, past promises became one of the stable features in an otherwise uncertain situation. These promises were reinforced by the conceptualisation of the end of the Cold War as a 'victory' for liberal democracy, capitalism, and western values. 
Dissidents had acted in the name of liberal democratic principles. Western leaders had recognised their responsibility to those upholding their ideals. With the collapse of communism, the West declared a victory, Each of these factors contributed to a transformation - once the context had changed - of promises from the past into threats. At this point we emphasise the eastern European context; in the next section, we return to an analysis of the two western organisations.

The CEECs referred to their liberation from Communism as a return to an original state, for instance, a return to the natural geographical and historical boundaries of Europe (Melescanu 1993), or a return to democracy, after a historical detour, and a return to capitalism and to history (Jeszenszky 1992). This ideal healthy state was not primarily a geographical or physical category, however; it was normative. As Romanian Foreign Minister Melescanu stated: 'today's Europe is to be found where its democratic, liberal and humanist values and practices succeed in shutting the door on the nightmare of authoritarian regimes, command economies, and a disregard for human rights and fundamental freedoms" (Melescanu 1993, 13). The model for this ideal healthy state was a set of shared western values going back to the Enlightenment and the democratic revolutions of the eighteen century. The problem in the years following the collapse was that western Europe wasn't doing enough to contribute to this outcome and in fact appeared to be isolating itself behind a new cordon sanitaire from the problems of post-Cold War Europe (Suchocka 1993: 6). The Cold War victor, who had challenged eastern bloc leaders to tear down the walls that kept eastern Europeans in, appeared, in the immediate aftermath of the Cold War, to be constructing barriers to keep them out.

The western effort to reconstruct a new border of order flew in the face of everything the central and eastern Europeans had expected from the West. Vaclav Havel (1991: 35), . speaking before NATO in the early 1990s, presented this expectation and the responsibility that flowed from it: 
The democratic West ... was for years offering sympathies to the democratic forces in the countries of the Soviet bloc.... The protection of democracy and human liberty to which it has been committed has given encouragement and inspiration to citizens of our countries, too.... The determination to resist evil has been a source of hope for millions of people who had to live under a yoke. Because of that, the West bears a tremendous responsibility.... To the West, whose civilisation is based on universal values, the fate of the East cannot be a matter of indifference for reasons of principle, and for practical reasons either. Instability, poverty, misfortune and disorder in the countries that have rid themselves of despotic rule could threaten the West just as the arms arsenals of the former despotic governments did (emphasis added).

The West, and its institutions, represented a normative ideal. The CEECs were encouraged to act in accordance with these ideals in resisting totalitarianism. Now that 'containment' of the Soviet Union was no longer necessary, the West had a rèsponsibility to assist the CEECs in the recovery, to assist them in upholding these values. Havel's appeal to western responsibility mirrored Carrington's recognition of this responsibility a decade earlier. Democracy was presented as a cure for eastern ailments, but, given the painful nature of the reforms, and the unhealed wounds reopened by the spirit of freedom, democracy would potentially give rise to - and by 1993 had given rise to - social unrest and national conflict, most notably in former Yugoslavia where war had broken out (Gazdag 1992). The West had encouraged the adoption of ideals, had celebrated the hope and possibility of prosperity and democracy, but the prescribed cure, rather than contributing to recovery, was exacerbating tensions. The EU was accused of only a lukewarm response to eastern problems, and NATO of isolating itself behind a new cordon sanitaire from the problems confronted by the CEECs since the fall of communism (Suchocka 1993). 
The existence of norms supporting Eastward enlargement was dramatised by central and eastern Europeans who pointed to the discrepancy between western promises and actions. The Cold War promise to eastern Europe became, in a new context, a threat of instability should the West fail to act. But the threat went even deeper. As we will argue in the next section, a failure to act on the promise became a threat to the identity of both institutions.

\section{Redefining Interests: The Challenge to Institutional Identity}

The point of the last section was to illustrate how actors used the past promises of states to hold up a mirror to current practices. The mirror was first held up to the eastern Europeanregimes, who in signing the Helsinki Final Act, promised to respect human rights and then proceeded to abuse the rights of dissidents who-morally supported by western governments--pointed out the discrepancy. In the immediate aftermath of the Cold War, these same dissidents, many of whom had become state leaders, held a mirror up to western governments, arguing that they, as the embodiment of the victory of liberal ideals in the Cold War, had a responsibility to those they had encouraged to adopt those ideals. These processes of mirroring provide a point of departure for rethinking the role of norms in processes of interest transformation.

These acts of exposing a descrepancy cannot be accounted for by rationalist theories. Given the emphasis on individuals or states as purely self-regarding egoists, rationalists assume that promises will not be respected if they are in conflict with one's self interest, regardless of others. However, if one's identity and ability to act are understood to be fundamentally social and, therefore, dependent on the recognition of others, promise-keeping becomes extremely important. It is at the point that others recognise the violation of normative expections or the failure to live up to previously stated ideals, that shame or disrespect are experienced. As Honneth (1995: 259) points out, it is not in the positive affirmation of norms that one's constitutive dependence on recognition from others is evident, 
but in the inability to continue with action once confronted with the discrepancy. The ability of states or alliances to act is as dependent on the positive recognition of identity as it is for individuals. Both rely on some measure of acceptance of an alignment between ideals or moral argument and practice.

In the aftermath of the Cold War the CEECs were seeking recognition from the West But western identity was also dependent on recognition. Too great an inconsistency between the normative ideals which the West represented and its practices toward the CEECs would be damaging to the identity of the EU and NATO, not to mention those elites in the CEECs who were attempting to provide a democratic carrot rather than a nationalist stick (Allin 1995). The institutional challenge took a somewhat different form for the two organisations, however.

In the case of the EU, the prospect of inclusion was offered to all European states that shared the its goals (Preamble to SEA, 1987). The responsibility of Europe as a whole, to increasingly speak in one voice and the necessity for all democratic European states to be represented by and through the European Parliament was emphasised with the 1991 Maastricht Treaty in the provision that "Any European State may apply to become a member of the Union" (Article O, TEU). This promise was enhanced at the 1993 Copenhagen Summit's Conclusions of the Presidency which stipulated

membership requires that the candidate country has achieved stability of institutions guaranteeing democracy, the rule of law, human rights and respect for protection of minorities. $^{15}$

The Amsterdam Treaty restates the intention to enlarge and explicitly the democratic condition, stipulating that " $[\dot{\mathrm{A}}]$ ny European State which respects the principles set out in

\footnotetext{
${ }^{15}$ Bulletin of the European Communities 6, 1993, point I.13.
} 
Article 6(1) may apply to become a member of the Union. (Article 49 TEU). ${ }^{16}$ In sum, the Amsterdam acquis communautaire entails the promise of enlargement on the condition that the candidates states be European, governed democratically, and based on the principle of law.

A key factor in for the current round of enlargement is the context in which it takes place. The absence of the Cold War border of order has influenced this process significantly. Candidate states have historically been required to accept the acquis communautaire in joining. The same is true in the current membership negotiations. While an accession of this scope requires a reshuffling of the EU's institutional balance, the 1996-97 intergovernmental conference (IGC) at Amsterdam postponed a decision in this respect until the point when membership would exceed 20 states. ${ }^{17}$ However, as some observed, it is not obvious why 20 members should come to an agreement that 15 could not reach. ${ }^{18}$ At any rate, the unresolved question of institutional balance at Amsterdam does present a hurdle in the enlargement process. Postponing the decision reflects a creeping insecurity in handling the process among EU member states. Effectively, this insecurity represents a gradual move away from previous promises of enlargement, uttered in the cold war context. The new emphasis on the conditions for enlargement, rather than the promise to do so, suggests that the EU is now less ready to take on the responsibility it assigned for itself at a time when eastern enlargement was not, yet, in sight.

More recent documents reveal the addition of new conditions for inclusion, for example, the respect of minorities. While the condition fits well with the shared norms of

\footnotetext{
${ }^{16}$ Former Article O; According to Article 6 (1) TEU "The Union is founded on the principles of liberty, democracy, respect for human rights and fundamental freedoms, and the rule of law ... shall respect fundamental rights, as guaranteed by the European Convention for the Protection of Human Rights and Fundamental Freedoms ... and as they result from the constitutional traditions common to the Member States, as general principles of Community law."

${ }^{17}$ On the IGC's failure to focus on institutional balance, see Sedelmeier 1999 forthcoming, Falkner and Nentwich 1999 forthcoming, Moravcsik and Nicolaidis 1998.

${ }^{18}$ European Policy Center, September 1997, http://europa.eu.int/en/agenda/igchome/instdoc/universe/europe.htm, p. 1 and p. 2 respectively.
} 
liberal democracy, it is striking to note that it is not explicitly mentioned in the acquis communautaire. In a sense then, eastern candidate countries are confronted with specific hurdles that create a tension between promises of the past, and their slow realisation in the present. Indeed, a shifting interest in enlargement could be detected during the Austrian Council Presidency of the EU when the actual accession negotiations with individual candidate countries began on 10 November 1998. With accession in view, some political actors openly expressed worries about security, human rights, minority politics, and threats to employment security, and subsequently cautioned against enlarging too rapidly.

On 1 July 1998, the Austrian Council President, foreign Minister Wolfgang Schüssel stressed, that "concern is now mounting that the date for the enlargement of the EU to take in countries from eastern European and Cyprus will be put back as the countries concerned struggle to meet EU standards." ${ }^{19}$ While negotiations had formally opened under the British presidency, Mr Schüssel warned that not only would the new countries have to make strenuous efforts but the EU would have to undertake major reforms before enlargement could go ahead. He said that "Even the Union itself is currently not yet in any fit state to take in new members." ${ }^{20}$ And Austrian MEP Hannes Swoboda stressed that "not only Austrians but also people in the candidate countries were anticipating this project of the century (EU enlargement) with concern. It would be irresponsible to forcefully push both $\mathrm{EU}$ and the candidate countries towards hastened enlargement." At the same time, the event was praised as a "historical day", as an achievement that had been "a particular concern of the Austrian presidency" and, as Schüssel further stressed, the accession conferences beginning in Vienna signify the "return to Europe of Hungary and other eastern European partners after more than eighty years of the breakdown of the Austrian-Hungarian monarchy." 21

\footnotetext{
${ }^{19}$ EP NEWS, July 1998, p. 1

${ }^{20}$ EP NEWS, July 1998, p. 1 [emphasis added]

${ }^{21}$ All citations from Der Standard, 10. November 1998, translation from German original, AW.
} 
Since the beginning of the German EU Presidency in January 1999 , the financial burden of enlargement has emerged as a major constraint and EU member states began quarrelling amongst themselves over who will bear the financial brunt of eastern enlargement. The German ministry of state expressed suspicion that other member states have high hopes for the Germans to "pay it all",22 and that without successful budgetary reforms, enlargement was not likely to happen any time soon. Chancellor Gerhard Schröder of Germany said that "The century of European integration will see little success if burden-sharing is not distributed on a more equal basis." ${ }^{23}$ Despite these financial constraints, the German Presidency of the EU continues to reassure the CEECs with statements about the obligation to enlarge. As German Secretary of State and President of the Council of Ministers, Joschka Fischer stated, After the Cold War the EU must not be limited to Western Europe, instead, at its core the idea of European integration is an all-European project. Geopolitical realities do not allow for a serious alternative anyhow. If this is true, then history has already decided about the 'if of eastern enlargement, even though the 'how' and 'when' remain to be designed and decided. ${ }^{24}$

The at times contradictory comments on enlargement as a historical opportunity, on the one hand, and a potential burden, on the other, point to the conflicting interests in the context of the enlargement discussion. An EU identity based on western democratic principles, and the related promise of enlargement, is at odds with emerging policy problems. Continuity in the enlargement process, despite these concerns, can be explained in terms of the norms and values that constitute EU identity. The strong role of these norms was expressed in the European Parliament's Oostlander Report that cautioned against "manoeuvring" aimed at postponing the opening of negotiations until there are precise details about the cost of

${ }^{22}$ Die Woche, 5 February 1999, 21

${ }^{23}$ Die Woche, 8 January 1999

${ }^{24}$ Die Zeit, 21 January 1999, 3 
enlargement. It maintains that with too much manoeuvre "enlargement will never take place. 25

The issues raised by the end of the Cold War were somewhat different for NATO. As a military alliance, designed for the defence of the West, the key question initially was less whether NATO would expand than whether the Alliance was necessary in the absence of its former antagonist. Lacking the institutional equivalent of the EU acquis regarding new members, NATO expansion was far from apparent. While NATO had 'won' the Cold War publics and parliaments on both sides of the Atlantic were reluctant to direct resources to the organisation in the absence of any obvious threat (Lubkemeier, 1991; Ando, 1993). Neither NATO nor the countries of central and eastern Europe assumed that NATO would militarily expand to the East. Yet, through a series of moves over several years the expansion became inevitable. ${ }^{26}$ The motor of this transformation was the conflict between two promises.

We have explored how the CEECs gave meaning to their struggle for recognition by the West. They argued that failure to expand would give rise to disorder. By contrast, one of NATO's arguments against military expansion was that it would arouse fears in Russia that the West sought domination over its former enemy and exacerbate xenophobic sentiments on the part of the Russian population (Taylor 1991; Holst 1992). Russia had articulated its opposition to expansion but then made a surprise move in August 1993 in signing the Russian-Polish declaration which granted Poland leave to join the Alliance. Yeltsin's act was viewed hopefully by the CEECs, but not in Russia. Instead, 'non-democratic' forces interpreted the possibility of NATO expansion as a move to re-establish the Cold War and isolate Russia (Ignatenko 1994; Sturua 1994).

The strong Russian reaction created some nervousness in the West, which was reflected in NATO's Brussels Summit in January 1994. Faced with pressure from the CEECs

${ }^{25}$ Together in Europe. European Union Newsletter for Central Europe, No 88, May 1st, 1996, p. 5, Rapporteur Arie Oostlander, Report approved on 17 April 1996.

${ }^{26}$ For a more indepth analysis of NATO expansion, see: Fierke (1999). 
to join the Alliance, and with the prospect that a decision to expand would mobilise nationalist forces in Russia, NATO mapped a middle course by creating the Partnership for Peace (PfP). The PfP would make it possible to delay the decision about expansion but, at the same time, would allow the CEECs to prepare for such an eventuality. While the West initially sought to mollify nationalist and communist forces in Russia through the PfP, the CEECs, concerned about the same development, emphasised the promise of the Partnership to prepare candidates for future membership. The Polish Minister of Defence Kolodziejcyk referred to the January Summit and the proclamation of the PfP.by the Alliance: 'We expect and would welcome NATO expansion that would reach to democratic states to our East.: He further stated that Poland undertook the Partnership as "the best route towards it goal of full integration in the Alliance' (Kolodziejcyk 1994). Poland drew on the promise of the PfP to press Polish interests.

At the beginning of 1994 NATO said there would be no immediate enlargement. By mid-1994, after Clinton's speech in Warsaw, momentum had shifted towards enlargement. ${ }^{27}$ At the December 1994 Brussels meeting of NATO foreign ministers, a decision was made to proceed with expansion. NATO expansion was placed in the context of building a European security architecture which would extend to the whole of Europe. While it was initially avoided out of fear that it would recreate the division of Europe, by 1996 it was said to have rendered the idea of dividing lines in Europe 'obsolete' (Moltke 1996). Any distinctions between countries as a result of expansion would be 'contours' indicating 'degrees of difference' rather than dividing lines. By developing a 'true partnership' with Russia and making a conceptual linkage between EU and NATO enlargement, expansion was to communicate the parallelism of integration and co-operation: the integration of new members

\footnotetext{
${ }^{27}$ The American congress and public opinion were once again asking why they should continue to invest in the Alliance, given the failure to take effective action in Bosnia (Sloan 1994; Aspin 1994). At the same time, Alliance countries were faced with major cuts in defence spending and renewed questions about the relevance and need for NATO in the absence of a Soviet threat (Bruce 1994; Sloan
} 
and the deepening of co-operation with those nations who are not, or not yet, ready or willing to join (Voigt 1996).

Like past applicants to the EU, the CEECs viewed membership in the two organisations as part of the same package. Even though the initial concern of the CEECs was an economic one, the challenge was raised to both organisations. Through a series of incremental decisions, not least of which was the creation of the PfP, the Visegrad countries emphasised those parts of the promise which would contribute to their eventual membership. Once a decision had been made to.include the Visegrad countries, the threat began to focus on a more traditional security concern and the promise to avoid new 'spheres of influence' in Europe, as leaders of the Baltic states pointed to promises by American leaders that 'No nation in Europe should ever again be consigned to a buffer zone between great powers or related to another nation's 'sphere of influence. ${ }^{28}$ The problem NATO presently faces is the conflict between its promise to expand to the Baltic states and its promise of genuine partnership with Russia, which opposes a further wave of expansion.

While NATO's interests may have originally been driven by a survival concern, the contradictions of the present situation open up two alternatives which are contrary to this interest, in so far as survival, in this case, is primarily a question of institutional relevance. The one is to transform the survival problem into one of military survival by respecting the promise to the Baltic states at the expense of its promise to Russia of genuine partnership. The other is to deepen the partnership with Russia at which point NATO's identity, and therefore survival as NATO, may become doubtful; the deeper the co-operation with Russia the less need there is for an organisation focusing on the North Atlantic area as opposed to a panEuropean security organisation, such as the OSCE. ${ }^{29}$

1994; Rose 1994). Expansion was the answer to these problems. The desire of the CEECs to join the Alliance became proof of its continuing relevance and mission (Aspin 1994).

${ }^{28}$ Warren Christopher, as quoted in: Stankevicius 1996; Golob 1996

${ }^{29}$ For a more indepth analysis see Fierke 1998, Chs. 10 and 11. 
In conclusion, an approach that identifies the relationship between contextual changes, normative ideals and institutional expansion for each of the three players-EU, NATO and the CEECs-provides insight into the rationale for expansion by placing both western organisations in a changing intersubjective context, which has been transformed through the interaction of the different players. The changing context was more dramatic for the CEECs than the West. While it constructed the possibility for the former to articulate two compatible interests, i.e. inclusion in both NATO and the EU, it created conflicting interests for both western organisations.

The changing context disrupted the future plans of the EU and NATO, presenting an entirely new situation to which they had to respond. To maintain the identity as victor in the Cold War, western institutions had to act with some semblance of consistency with the normative ideals they represented. The promises of prosperity and democracy were stable and constant features against a backdrop of material disarray. The CEECs drew on these normative ideals to pressure the West to keep their promises. While failing to provide the massive assistance reminiscent of the Marshall Plan, both the EU and NATO did reinforce the promise of eventual inclusion. By making the CEECs responsible for their own readiness to join, the West also provided a carrot that would hopefully dampen the conflicting tendencies toward disintegration in the East. The promise constituted the possibility of expansion. Against the background of a dramatically changed context, the CEECs transformed the promise into a threat, making maximum use of their compatible interests in expansion by both institutions. By contrast, NATO and the EU were pulled toward expansion against the background of conflicting interests.

\section{The Challenge of Eastern Enlargement and the Constructivist Research}

\section{Programme}


Comparing EU and NATO expansion provides insight into the expansion process in a way that an analysis of either organisation, in and of itself, cannot. We have argued that an explanation of both processes, against the odds, requires embedding policy decisions in a normative order which does not exclude the EU's acquis but is larger and encompasses NATO as well. When embedded in this normative order, moves to redefine EU and NATO interests regarding expansion can be understood as emerging out of the tension between past promises and on-going practice in a context of dramatic change, which, in the absence of the old border of order, constituted a challenge to the Cold War identities of the two institutions. To demonstrate the impact of this change, we examined a process of norm construction which preceded the critical juncture of the end of the Cold War. We also elaborated the relationship between norms, practices and identity, and how interests were transformed in the dialectical relationship between the three. In doing so, our analysis fits squarely within the constructivist debate but pushes further.

While the constructivist emphasis on identities, norms and practices provides an important point of departure for understanding the expansion process, we note that this literature has not sufficiently addressed issues raised by a context of dramatic change where the 'other' disappears or undergoes significant transformation. Our argument includes the following components. First, the enlargement decisions have to be embedded in a longer process going back to the construction of norms during the Cold War. The key issue is how the meaning of speech acts embodying these norms changed with the end of the Cold War, and how this constructed the conditions for eastern enlargement. The argument rests on a dialectical relationship between context, speech acts and institutional change. The rationality of moves by either organisations has to be situated in a context of past meanings.

Second, we emphasise that context and speech acts are explicitly intersubjective. As a result, we assume the importance of the meanings actors bring to their own actions and the material world around them. This points to the role language as onother crucial element that 
has not been adequately addressed in some of the constructivist literature. The reluctance to take language seriously undoubtedly relates to a widespread acceptance of the realist assumption that the primary speech-act of diplomats is the lie and that states will break promises if it is in their interest to do so. By analysing 'promises' as a specific form of action, and looking at processes by which the two institutions were held to account for their promises and normative ideals, we turn the realist argument about language on its head.

Third, if meaning is dependent on context, it follows logically that, as a context changes, so will the meaning of acts. We argue that the promise of western institutions, held out to the former eastern bloc during the Cold War, was transformed into a threat, by both East and West, with the dismantling of the European division and the Soviet Union. This new threat gave rise to a conclusion that the CEECs could not be excluded, over the long term, from western organisations. If western acts were not consistent with past promises, the consequence would be a loss of popular support for democratic institutions and a free market economy, which would exacerbate nationalist tensions and ethnic rivalries in the region creating a security threat for the West. The threat not only took the form of potential instability in the East, however; the failure to fulfil the promise, and the exposure of this failure, presented a threat to the identity of the two organisations.

\section{References}

Alexander, M. (1991) 'European Security and the CSCE,'NATO Review, 39 (4): 10-14. Allin, Dana (1995) 'Can Containment Work Again?' Survival, 37 (1): 53-65. Ando, Salvo (1993), 'Preparing the Ground for an Alliance Peacekeeping Role,' NATO Review, 41 (2): 4-9.

Asmus, R, Kugler R. and Larrabee F. S. (1995) 'NATO Expansion: The Next Steps,' Survival, 37 (1): 7-33.

Aspin, Les (1994) New Europe, new NATO.' NATO Review, 42 (1): 12-14. Avery, Graham and Fraser Cameron (1998) The Enlargement of the European Union. Sheffield: Sheffield Academic Press. 
Bloed, A., ed. (1990) From Helsinki to Vienna: Basic Documents of the Helsinki Process. Dordrecht: Martinus Nijhoff.

Brown, M. E. (1995) 'The Flawed Logic of NATO Expansion,' Survival 37 (1): 34-52.

Bruce, Erika (1994) 'NATO's Information Activities at a Time of Increasing Demands and Dwindling Resources.' NATO Review, 42 (4): 17-19.

Buzan, B., Waever, O., and de Wilde, J. (1998) Security: A New Framework for Analysis. Boulder: Lynne Rienner.

Carmoy, G. de. (1982) 'Defence and Détente: Two Complementary Policies," NATO Review, $30(2)$.

Campbell, David (1998) 'Epilogue: The Disciplinary Politics of Theorizing Identity,' Writing Security: United States Foreign Policy and the Politics of Identity, revised edition.

Minneapolis: University of Minnesota Press.

Lord Carrington (1983) 'Lack of Consistent Political Strategy: A Case of Friction,' NATO Review 31 (2).

Christopher, Warren (1993) 'Towards a NATO Summit.' NATO Review, 41 (4): 3-6.

Defois, G. (1984) 'The Church and Deterrence,' NATO Review, 32 (3).

Doty, Roxanne (1997) 'Apioria: A Critical Exploration of the Agent-Structure Problematique in International Relations Theory,' European Journal of International Relations, 3 (3).

Duffy, G., Frederking, B., and Tuck, S.A. (1998) 'Language Games: Dialogical Analysis of INF Negotiations,' International Studies Quarterly, 42 (2): 271-294.

Fierke, K.M. (1999), 'Dialogues of Manoeuvre and Entanglement: NATO, Russia and the CEECs, 'Millenium, forthcoming.

Fierke, K.M. (1998) Changing Games, Changing Strategies: Critical Investigations in Security. Manchester: Manchester University Press.

Finnemore, Martha. (1996) 'Norms, Culture and World Politics: Insights from Sociology's Institutionalism." International Organization, 50: 325-347.

Finnemore, Martha and Kathryn Sikkink (1998) 'International Norm Dynamics and Political Change.' Ms 1998.

Gazdag, F. (1992) 'Does the West Understand Central and Eastern Europe?' NATO Review_40 (6).

George, B. (1993) 'Alliance at the Flashpoint of a New Era," NATO Review, 41 (5).

Gialdino, Carlo Curti (1995) 'Some Reflections on the Acquis Communautaire.' Common Market Low Review 32:1089 - 1121.

Glaser, C. L. (1993) 'Why NATO is Still Best: Future Security Arrangements for Europe,' International Security, 18 (1): 5-50.

Golob, I. (1996) 'Preparing for Membership:Slovenia's Expanding Ties to NATO,' NATO Review, 44 (6).

Grabbe, Heather and Kirsty Hughes (1998) Enlarging the EU Eastwards. London: The Royal Institute of.International Affairs.

Havel, Vaclav. (1991) 'Address to the NATO Council.' NATO Review, 39 (2): 31-35.

Holst, J.J. (1992) 'Pursuing a Durable Peace in the Aftermath of the Cold War.' NATO Review, $40(4): 9-13$. 
Honneth, Axel (199) The Fragmented World of the Social: Essays in Social and Political Philosophy. Albany, NY: State University of New York Press.

"Implementation of the Final Act of the CSCE," (1976), NATO Review, 24 (2).

Ignatenko, A. (1994) 'American Diplomacy is Stepping Up its Activity on Russia's Southern Borders.' Nezavisimaya gazeta. In: Current Digest of the Post-Soviet Press 10.

Jeszenszky, G. (1992) 'Nothing Quiet on the Eastern Front,' NATO Review, 40 (3)

Kolodziejczyk, Piotr. (1994) 'Poland - a Future NATO Ally.' NATO Review, 42 (5): 7-10.

Katzenstein, Peter, ed. (1996a). The Culture of National Security. New York: Columbia University Press.

Katzenstein, Peter (1996b). Cultural Norms \& National Security. Ithaca and London: Cornell University Press.

Keohane, Robert O. (1988) 'International Institutions: Two Approaches.' International Studies Quarterly, 32: 379-396.

Klotz, Audie (1995) Norms in International Relations. The Struggle Against Apartheid. Ithaca and London: Cornell University Press.

Koslowski, Rey and Friedrich Kratochwil (1994) 'Understanding Change in International Politics: The Soviet Empire's Demise and the International System.' International Organization 48: 215 - 247.

Kratochwil, Friedrich (1994) 'Citizenship: The Border of Order.' Alternatives 19.

Kratochwil, Friedrich (1989) Rules, Norms, and Decisions. On the Conditions of Practical and Legal Reasoning in International Relations and Domestic Affairs. Cambridge: Cambridge University Press.

Levi, A. (1982) 'Western Values and the Successor Generation, NATO Review, 30 (2).

Levinson, Stephen (1983) Pragmatics. Cambridge: Cambridge University Press.

Lubkemeier, E. (1991) 'The Political Upheaval in Europe and the Reform of NATO Strategy,'. 30 (3).

Luns, J. (1979) 'Thirty Years Later: Aims of the Alliance Still Valid,' NATO Review, 27 (2) Mandelbaum, M. (1996) The Dawn of Peace in Europe. New York: The Twentieth Century. Fund.

McCalla, R. B. (1996) 'NATO's Persistence after the Cold War,' International Organization, $50(3): 445-475$.

MccGwire, Michael (1998) 'NATO Expansion: 'A Policy Error of Historic Importance.' Review of International Studies, 24 (1): 23-42.

Melescanu, Teodor (1993) 'Security in Central Europe: A Positive-Sum Game.' NATO Review, 41 (5): 12-18.

Michalski, Anna and Helen Wallace (1992) The European Community: The Challenge of Enlargement. London: Royal Institute of International Affairs.

Moltke, Gebhardt Von. (1996) 'NATO moves toward Enlargement,' NATO Review, 44 (1): 36.

Nimetz, M. (1980) 'CSCE: Looking to Madrid,' NATO Review, 29(2). 
Onuf, N. (1989) World of Our Making: Rules and Rule in Social Theory and International Relations. Columbia, SC: University of South Carolina Press.

Preuss, Ulrich (1995) 'Citizenship and Identity: Aspects of a Political Theory of Citizenship,“ in Vittorio Bufacchi and Dario Castiglione Richard Bellamy (eds.), Democracy and Constitutional Culture in the Union of Europe. London: Lothian FP.

Rose, Charlie (1994) 'Democratic Control of the Armed Forces. A Parliamentary Role in 'Partnership for Peace.' NATO Review. 42 (5): 13-19.

Schimmelpfennig, Frank (1998) 'The Eastern Enlargement of the European Union. A Case for Sociological Institutionalism,' in Joint Conference of the DVPW, OEGPW, and SVPW "Europe Between Integration and Exclusion". Vienna.

Sedelmeier, Ulrich (1998) The European Union's Association Policy towards the Countries of Central and Eastern Europe: Collective EU Identity and Policy Paradigms in a Composite Policy, Unpubl. Ph.D. Dissertation, University of Sussex.

Sedelmeier, Ulrich (1999) 'East of A'dam: the Amsterdam Treaty's Implications for Eastern Enlargement,' in Karlheinz Neunreither and Antje Wiener (eds.) European Integration After Amsterdam: Institutional Dynamics and Prospects for Democracy. Oxford: Oxford University Press (forthcoming).

Sloan, Stanley (1994) 'Transatlantic Relations in the Wake of the Brussels Summit.' NATO Review, 42 (2): 27-31.

Sloan, S. (1995) 'U.S. Perspectives on NATO's Future ${ }_{2}^{\prime}$ International Affairs, 71 (2): 217-46.

Solesby, T. (1978) 'Helsinki to Belgrade - and Beyond,' NATO Review, 26 (3).

Stankevicius, Ceslovas (1996) NATO Enlargement and the Indivisibility of Security in Europe: A view from Lithuania,' NATO Review 44 (5): 21-25.

Sturua, Melor (1994) 'Every President Needs a Devil's Advocate," Izvestia, January 12. As reprinted in: 'Military Alliances,' Current Digest of the Post-Soviet Press, 66 (2): 31.

Suchocka, Hanna (1993) 'Poland's European Perspective,' NATO Review 41 (3): 3-6.

Taylor, Trevor (1991) 'NATO and Central Europe,' NATO Review 39 (5): 17-22.

Voigt, Karsten (1996) 'NATO Enlargement: Sustaining the Momentum,' NATO Review 44 (2): $15-19$.

Waever, Ole. 1996. "The Rise and Fall of the Inter-paradigm Debate." Pp. 149-185 in Steve Smith, et.al. (eds.) International Theory: Positivism \& Beyond. Cambridge: Cambridge University Press: 149-185.

Wendt, A. (1992) 'Anarchy is What States Make of It: The Social Construction of Power Politics, 'International Organization, 46 (2): 393-425.

Wendt, Alexander (1994) 'Collective Identity Formation and the International State,' American Political Science Review, 88 :84-96.

Wiener, Antje (1998a) 'European' Citizenship Practice - Building Institutions of a Non-State. Boulder, CO: Westview Press.

Wiener, Antje (1998b) 'The Embedded Acquis Communautaire. Transmission Belt and Prism of New Governance.' European Law Journal 4:294-315.

Worner, Manfred (1991) "NATO Transformed: The Significance of the Rome summit." NATO Review 39 (6): 3-6.

Worner, Manfred (1994) 'Shaping the Alliance for the Future.' NATO Review 42 (1): 3-6. 
Zehfuss, Maja (1998), Sprachlosigkeit schränkt ein. Zur Bedeutung von Sprache in konstruktivistischen Theorien.' Zeitschrift für internationale Beziehungen 5:109-137. 